\title{
Organosilicone Adjuvants Increased the Efficacy of Glyphosate for Control of Weeds in Citrus (Citrus spp.)
}

\author{
Krishna N. Reddy ${ }^{1}$ and Megh Singh ${ }^{2}$ \\ Citrus Research and Education Center, University of Florida, Institute of \\ Food and Agricultural Sciences, 700 Experiment Station Road, Lake \\ Alfred, FL 33850 \\ Additional index words. surfactant, Richardia scabra, Digitatia ciliaris, Bidens pilosa,
Heterotheca subaxillaris, Paspalum notatum, Cynodon dactylon, Panicum repens
}

Abstract. A field study was conducted to evaluate the effectiveness of Kinetic and Sylgard 309 organosilicone adjuvants to increase the efficacy of glyphosate for control of Florida pusle (Richardia scabr a L.), southern crabgras [Digitaria ciliaris (Retz.) Koel], hairy beggartick (Bidens pilosa L.), camphorwed [Heterotheca subaxillaris (Lam.) Britt. and Rusby], bahiagras (Paspalum notatu $m$ Fluegge), bermudagras [Cynodon dactylo $n(\mathrm{~L}$.$) Pers.], and torpedogras (Panicum repen s$ L.). Glyphosate, either at 0.5 or $1.0 \mathrm{~kg}$ a.i./ha, was applied alone or in combination with Kinetic, Sylgard 309, or X-77 using a tractor-mounted boom sprayer that delivered 187 liters'ha ${ }^{-1}$ at 207 kPa pressure. Glyphosate applied at $0.5 \mathrm{~kg} \cdot \mathrm{ha}^{-1}$ controlled $>94 \%$ of Florida pusley, southern crabgrass, hairy beggarticks, and camphorweed. Glyphosate efficacy improved on Florida pusley and southern crabgrass when applied with the adjuvants. Glyphosate, regardless of adjuvant, completely controlled hairy beggarticks and camphorweed. Control of bahiagrass, bermudagrass, and torpedograss with adjuvants was better than without adjuvants. However, glyphosate with Kinetic or Sylgard 309 was more effective in suppressing regrowth of these perennial grasses than glyphosate with $\mathrm{X}-77$. Chemical names used: isopropylamine salt fo $N$-(phosphonomethyl)glycine with an in-can surfactant (glyphosate); proprietary blend of polyalkyleneoxide-modified polydimethylsiloxane and nonionic organosilicone adjuvant (Kinetic); silicone adjuvant mixture of 2-(3.hydroxypropyl)-heptamethyltrisiloxane, ethyloxylated, acetate EO glycol, -allyl, -acetate (Sylgard 309); mixture of alkylarylpolyoxyethylene glycols, free fatty acids, and isopropanol nonionic adjuvant (X-77).

The temperate to subtropical climate of Florida is favorable for year-round germination and growth of weeds. Abundant moisture (high annual rainfall and irrigation) and frequent fertilization further aggravate the weed problems in citrus (Citrus spp.)

\footnotetext{
Received for publication 16 Dec. 1991. Accepted for publication 11 May 1992. Florida Agricultural Experiment Station Journal Series no. R-02061. Mention of a trademark, proprietary product, or vendor does not constitute a guarantee or warranty of the product by the Univ. of Florida and does not imply its recommendation to the exclusion of other products that may also be suitable. The cost of publishing this paper was defrayed in part by the payment of page charges. Under postal regulations, this paper therefore must be hereby marked advertisement solely to indicate this fact. 'Research Associate.

*Professor.
}

groves. Glyphosate (Monsanto, St. Louis), a nonselective postemergence herbicide, is used extensively for control and chemical mowing of weeds in citrus groves. Vulnerability of glyphosate to wash off plant foliage when rainfall occurs within 6 to $8 \mathrm{~h}$ after application limits its efficacy. Formulated glyphosate contains surfactant; therefore, enhanced activity of glyphosate with an additional spray adjuvant depends mainly on the type of adjuvant, weed species, and environmental factors. Various adjuvants have been evaluated for their ability to enhance glyphosate activity on several weeds (Jansen, 1973; Swietlik, 1989; Wyrill and Burnside, 1977). Recently, a few specific siliconebased adjuvants have been reported to be effective in increasing glyphosate efficacy in general and rainfastness in particular on several weed species (Field and Bishop, 1988;
Reddy and Singh, 1992; Roggenbuck et al., 1990).

Kinetic (Helena Chemical Co., Memphis, Tenn.) and Sylgard 309 (Dow Coming Corp., Midland, Mich.) are new silicone adjuvants that enhanced glyphosate activity and reduced the critical rain-free period (rainfast) to $\leqslant 1 \mathrm{~h}$ on several weed species under greenhouse conditions (Reddy and Singh, 1992; Roggenbuck et al., 1990). However, no information has been reported on the effectiveness of these adjuvants for increasing glyphosate activity under field conditions. The objective of this field study was to evaluate the effect of Kinetic and Sylgard 309 on efficacy of glyphosate to control four annual and three perennial weeds in citrus. X-77 adjuvant (Valent U.S.A. Corp., Walnut Creek, Calif.) was included in the study as a standard for comparison.

Annual weed control. A field study was conducted in 1991 in a citrus grove at Davenport Research Farm, Lake Alfred, Fla. The experimental area was infested naturally with high populations of Florida pusley, southern crabgrass, hairy beggarticks, and camphorweed. The experimental area was mowed 12 days before herbicide application to ensure uniform growth of weeds. Glyphosate was applied at 0.5 and $1.0 \mathrm{~kg} \cdot \mathrm{ha}^{-1}$ alone or with adjuvants on 11 June 1991 when the target weeds were $\approx 15 \mathrm{~cm}$ tall. The plots, $14 \mathrm{~m}$ long and $2.5 \mathrm{~m}$ wide, were established between citrus rows. Plots were replicated four times and arranged in two-factorial randomized complete blocks with glyphosate rate and adjuvant as the two factors. Herbicide treatments were applied using a tractormounted boom sprayer equipped with Teejet 8001SS nozzles. Tractor speed was 4.5 $\mathrm{km} \cdot \mathrm{h}^{-1}$, which delivered a spray volume of 187 liters $\cdot \mathrm{ha}^{-1}$ at $207 \mathrm{kPa}$ pressure. Weed control was evaluated visually at several time intervals on a scale of 0 (no control) to 100 (complete control). Data for each evaluation were subjected to two-factorial analysis of variance, and means were separated at $P=$ 0.05 using Fisher's LSD test. Data from untreated check plots were excluded in analysis of variance. Analysis of variance with or without arcsin transformation of data resulted in the same conclusions.

Glyphosate applied at 0.5 or $1.0 \mathrm{~kg} \cdot \mathrm{ha}^{-1}$ resulted in $>94 \%$ control of Florida pusley at 6 weeks after application (Table 1). Glyphosate applied with the adjuvants provided excellent (>98\%) control of Florida pusley compared to no adjuvant $(84 \%)$ at 6 weeks after application. Florida pusley control could 
Table 1. Control of four annual weeds with glyphosate applied with and without adjuvants. ${ }^{2, y}$

\begin{tabular}{|c|c|c|c|c|c|c|c|c|}
\hline \multirow[b]{2}{*}{ Treatments } & \multicolumn{2}{|c|}{$\begin{array}{l}\text { Florida } \\
\text { pusley }\end{array}$} & \multicolumn{2}{|c|}{$\begin{array}{l}\text { Southern } \\
\text { crabgrass }\end{array}$} & \multicolumn{2}{|c|}{$\begin{array}{c}\text { Hairy } \\
\text { beggarticks }\end{array}$} & \multicolumn{2}{|c|}{ Camphorweed } \\
\hline & $2 \mathrm{~W}^{\mathrm{x}}$ & $6 \mathrm{~W}$ & $2 \mathrm{~W}$ & $6 \mathrm{~W}$ & $2 \mathrm{~W}$ & $6 \mathrm{~W}$ & $2 \mathrm{~W}$ & $6 \mathrm{~W}$ \\
\hline & \multicolumn{8}{|c|}{$\%$ Control } \\
\hline $\begin{array}{l}\text { Nontreated check } \\
\text { Rate }\end{array}$ & 0 & 0 & 0 & 0 & 0 & 0 & 0 & 0 \\
\hline Glyphosate, $0.5 \mathrm{~kg} \cdot \mathrm{ha}^{-1}$ & $81 \mathrm{a}$ & 94 a & 99 a & $96 \mathrm{a}$ & $95 \mathrm{a}$ & $100 \mathrm{a}$ & $100 \mathrm{a}$ & $100 \mathrm{a}$ \\
\hline $\begin{array}{l}\text { Glyphosate, } 1.0 \mathrm{~kg} \cdot \mathrm{ha}^{-1} \\
\text { Adjuvant }\end{array}$ & 90 a & $95 \mathrm{a}$ & 99 a & $96 \mathrm{a}$ & $96 \mathrm{a}$ & $100 \mathrm{a}$ & $100 \mathrm{a}$ & $100 \mathrm{a}$ \\
\hline None & $74 \mathrm{~b}$ & $84 \mathrm{~b}$ & $98 \mathrm{a}$ & $85 \mathrm{~b}$ & $81 \mathrm{~b}$ & $100 \mathrm{a}$ & $100 \mathrm{a}$ & $100 \mathrm{a}$ \\
\hline $\mathrm{X}-17$ & $91 \mathrm{a}$ & $99 \mathrm{a}$ & $99 \mathrm{a}$ & $100 \mathrm{a}$ & $100 \mathrm{a}$ & $100 \mathrm{a}$ & $100 \mathrm{a}$ & $100 \mathrm{a}$ \\
\hline Kinetic & $95 \mathrm{a}$ & $98 \mathrm{a}$ & $100 \mathrm{a}$ & $100 \mathrm{a}$ & $100 \mathrm{a}$ & $100 \mathrm{a}$ & $100 \mathrm{a}$ & $100 \mathrm{a}$ \\
\hline Sylgard 309 & $94 \mathrm{a}$ & $99 \mathrm{a}$ & $100 \mathrm{a}$ & $100 \mathrm{a}$ & $100 \mathrm{a}$ & $100 \mathrm{a}$ & $100 \mathrm{a}$ & $100 \mathrm{a}$ \\
\hline $\operatorname{LSD}(5 \%)$ & & & & & & & & \\
\hline Rate $\times$ adjuvant & NS & NS & NS & NS & NS & --- & -- & -- \\
\hline
\end{tabular}

${ }^{2} \mathrm{X}-77$, Kinetic, and Sylgard 309 were used at $0.5 \%(\mathrm{v} / \mathrm{v})$.

${ }^{y}$ Mean separation within a column and rate or adjuvant by Fisher's LSD test, $P=0.05$.

${ }^{\mathrm{x}} \mathrm{W}=$ Weeks after glyphosate application.

${ }^{\text {Ns }}$ Nonsignificant at $P=0.05$.

Table 2. Bahiagrass control with glyphosate applied with and without adjuvants. ${ }^{2 .}$

\begin{tabular}{|c|c|c|c|c|c|}
\hline \multirow[b]{2}{*}{ Treatments } & \multicolumn{5}{|c|}{ Bahiagrass } \\
\hline & $2 \mathrm{~W}^{\mathrm{x}}$ & $6 \mathrm{~W}$ & $9 \mathrm{~W}$ & $12 \mathrm{~W}$ & $15 \mathrm{w}$ \\
\hline $\begin{array}{l}\text { Nontreated check } \\
\text { Rate }\end{array}$ & 0 & 0 & $\begin{array}{c}\text { \% Contr } \\
0\end{array}$ & 0 & 0 \\
\hline $\begin{array}{l}\text { Glyphosate, } 0.5 \mathrm{~kg} \cdot \mathrm{ha}^{-1} \\
\text { Glyphosate, } 1.0 \mathrm{~kg} \cdot \mathrm{ha}^{-1} \\
\text { Adjuvant }\end{array}$ & $\begin{array}{l}74 \mathrm{a} \\
75 \mathrm{a}\end{array}$ & $\begin{array}{l}100 a \\
100 a\end{array}$ & $\begin{array}{l}100 \mathrm{a} \\
100 \mathrm{a}\end{array}$ & $\begin{array}{l}89 \mathrm{a} \\
92 \mathrm{a}\end{array}$ & $\begin{array}{l}18 \mathrm{a} \\
82 \mathrm{a}\end{array}$ \\
\hline $\begin{array}{l}\text { None } \\
\text { X-71 } \\
\text { Kinetic } \\
\text { Sylgard } 309 \\
\text { LSD }(5 \%)\end{array}$ & $\begin{array}{l}68 \mathrm{~b} \\
71 \mathrm{~b} \\
65 \mathrm{~b} \\
93 \mathrm{a}\end{array}$ & $\begin{array}{l}100 \mathrm{a} \\
100 \mathrm{a} \\
100 \mathrm{a} \\
100 \mathrm{a}\end{array}$ & $\begin{array}{l}100 \mathrm{a} \\
100 \mathrm{a} \\
100 \mathrm{a} \\
100 \mathrm{a}\end{array}$ & $\begin{array}{l}88 \mathrm{a} \\
90 \mathrm{a} \\
92 \mathrm{a} \\
93 \mathrm{a}\end{array}$ & $\begin{array}{l}68 \mathrm{~b} \\
17 \mathrm{ab} \\
88 \mathrm{a} \\
88 \mathrm{a}\end{array}$ \\
\hline Rate $\times$ adjuvant & NS & --- & --- & NS & NS \\
\hline
\end{tabular}

${ }^{2} \mathrm{X}-77$, Kinetic, and Sylgard 309 were used at $0.5 \%(\mathrm{v} / \mathrm{v})$.

'Mean separation within a column and rate or adjuvant by Fisher's LSD test, $P=0.05$.

${ }^{\mathrm{x}} \mathrm{W}=$ Weeks after glyphosate application.

${ }^{\text {Ns }}$ Nonsignificant at $P=0.05$.

Table 3. Bermudagrass and torpedograss control with glyphosate applied with and without adjuvants. ${ }^{2, y}$

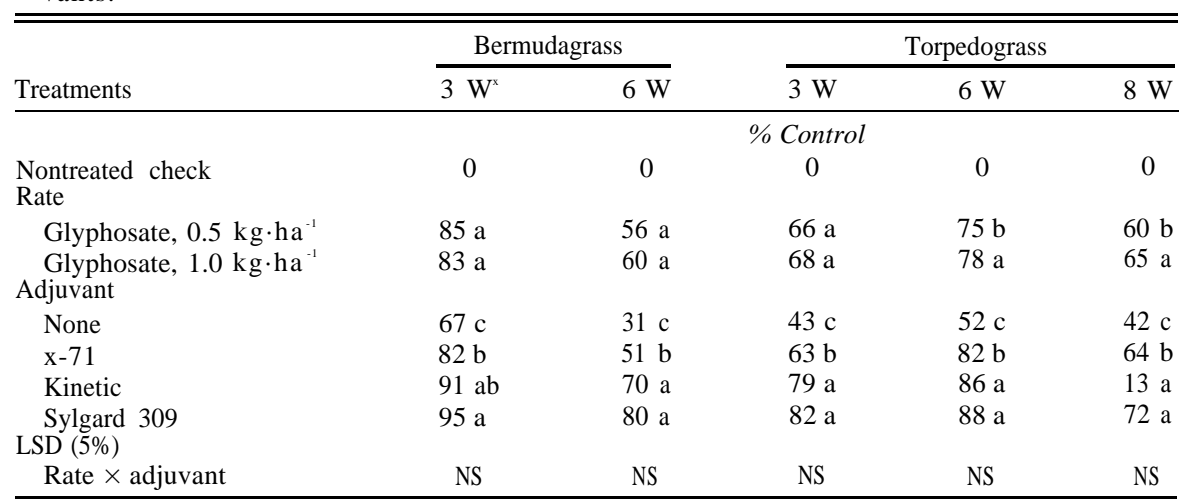

${ }^{2} \mathrm{X}-77$, Kinetic, and Sylgard 309 were used at $0.25 \%(\mathrm{v} / \mathrm{v})$.

'Mean separation within a column and rate or adjuvant by Fisher's LSD test, $P=0.05$.

${ }^{x} \mathrm{~W}=$ Weeks after glyphosate application.

${ }^{\text {Ns }}$ Nonsignificant at $P=0.05$.

not be evaluated beyond 6 weeks following application due to difficulty in differentiating between plants present at spraying and lategerminated plants. A similar trend was observed in southern crabgrass control. All treatments, regardless of glyphosate rate and adjuvant, completely controlled hairy beggarticks and camphorweed.

Bahiagrass control. A field study was conducted in 1991 at Lake Alfred Research Farm. The experimental area was infested naturally with high populations of bahiagrass. Herbicide treatments were applied on 11 June 1991. Treatments were replicated three times. All other experimental conditions, weed control evaluation, and statistical analyses were as described in the annual weed control experiment.
Bahiagrass control with glyphosate at either rate was similar at all evaluation intervals (Table 2). At 2 weeks after application, Sylgard 309 was effective in enhancing bahiagrass control compared to Kinetic or X-77. However, at 6 and 9 weeks after application, all treatments, regardless of glyphosate rate and adjuvant, completely controlled bahiagrass (Table 2). Regrowth of bahiagrass started at 12 weeks after application, and some differences among the treatments appeared at 1.5 weeks after application. Addition of Kinetic and Sylgard 309 adjuvants effectively suppressed bahiagrass regrowth compared to no adjuvant.

Perennial weed control. A field study was conducted in 1991 at Davenport Research Farm. The experiment was conducted on two plots that were infested naturally with high populations of either bermudagrass or torpedograss. Herbicide treatments were applied on 4 Sept. 1991. Treatments were replicated three times. All other experimental conditions, weed control evaluation, and statistical analyses were as described in the annual weed control experiment.

At 3 weeks after application, bermudagrass control generally improved when glyphosate was applied with adjuvants (Table 3). Sylgard 309 was more effective in increasing bermudagrass control than X-77. Bermudagrass regrowth had began in all treatments by 6 weeks after application. Kinetic and Sylgard 309 were more effective in suppressing bermudagrass regrowth than $\mathrm{X}-77$.

All adjuvants increased control of torpedograss with glyphosate compared to no adjuvant at 3 weeks after application, but Sylgard 309 and Kinetic were more effective than X-77 (Table 3). Overall, control of torpedograss improved slightly at 6 weeks after application in all treatments. Control of torpedograss decreased in general by 8 weeks after application; however, regrowth suppression was better when glyphosate was applied with adjuvants, particularly Sylgard 309 and Kinetic.

Glyphosate applied with and without adjuvants can effectively control the four annual weeds studied (Table 1). Since no 
treatments gave $100 \%$ control of difficult-tocontrol perennial weeds, such as bahiagrass, bermudagrass, and torpedograss, repeated applications or higher rates of glyphosate or both are required for complete control of these weeds. We stress, however, that the recommended rate of glyphosate for control of some annual and perennial weeds can be as high as $3.0 \mathrm{~kg} \cdot \mathrm{ha}^{-1}$. Overall, Sylgard 309 and Kinetic enhanced glyphosate activity on three problem perennial grasses and may be worth adding to herbicide spray solution, especially since they have been reported to in- crease rainfastness of glyphosate (Reddy and Singh, 1992; Roggenbuck et al., 1990).

\section{Literature Cited}

Field, R.J. and N.C. Bishop. 1988. Promotion of stomatal infiltration of glyphosate by an organosilicone surfactant reduces the critical rainfall period. Pesticide Sci. 2455-62.

Jansen, L.L. 1973. Enhancement of herbicides by silicone surfactants. Weed Sci. 21:130-135.

Reddy, K.N. and M. Singh. 1992. Organosilicone adjuvant effects on glyphosate efficacy and rainfastness. Weed Technol. 6:361-365.

Roggenbuck, F.C., L. Rowe, D. Penner, L. Petroff, and R. Burow. 1990. Increasing postemergence herbicide efficacy and rainfastness with silicone adjuvants. Weed Technol. 4:576580.

Swietlik, D. 1989. Adjuvants affect the efficacy of glyphosate on selected perennial weeds. HortScience 24:470-472.

Wyrill, J.B., III, and O.C. Burnside. 1977. Gly phosate toxicity to common milkweed and hemp dogbane as influenced by surfactants. Weed Sci. 25:275-287. 